\title{
LETHAL TEMPERATURES FOR Rhamdia quelen LARVAE (PIMELODIDAE) ${ }^{1}$
}

\author{
TEMPERATURAS LETAIS DE LARVAS DE Rhamdia quelen (PIMELODIDAE)
}

\section{Adriana Regina Chippari-Gomes ${ }^{2}$ Levy Carvalho Gomes ${ }^{2}$ Bernardo Baldisserotto $^{3}$}

\section{- SHORT NOTE -}

\section{SUMMARY}

The lower and upper lethal temperatures $\left(L T_{50}\right)$ of $\boldsymbol{R}$. quelen larvae were determined. The larvae were obtained from two spawning periods with hatching temperatures of 21 and $26^{\circ} \mathrm{C}$ respectively. Larvae were placed in tanks at which the temperatures were either increased $1^{\circ} \mathrm{C}$ every $15 \mathrm{~min}$, or reduced $1^{\circ} \mathrm{C}$ every $20 \mathrm{~min}$ until larval movement ceased. This temperature was then maintained for 96h. Minimum mortality $(29.0 \pm 1.5 \%)$ was observed in the larvae held at hatching temperatures. The lower $L T_{50}$ were 15.01 and $16.72^{\circ} \mathrm{C}$, and the upper $L T_{50}$ were 29.25 and $27.83^{\circ} \mathrm{C}$ for the larvae hatching at 21 and $26^{\circ} \mathrm{C}$, respectively. Thus, apparently there is no difference with relation to temperature change tolerance between larvae hatched in both temperatures.

Key words: Rhamdia quelen, larvae, lethal temperatures, hatching, silver catfish.

\section{RESUMO}

Foram determinadas as temperaturas letais $\left(T L_{50}\right)$ inferiores e superiores de larvas de $\boldsymbol{R}$. quelen. As larvas foram obtidas em dois períodos de desova com temperatura de incubação de 21 e $26^{\circ} \mathrm{C}$, respectivamente. Larvas foram colocadas em aquários onde a temperatura foi elevada em $1^{\circ} \mathrm{C}$, a cada $15 \mathrm{~min}$, ou reduzida $1^{\circ} \mathrm{C}$, a cada 20min, até as larvas cessarem seus movimentos. Esta temperatura foi então fixada e mantida por 96h. O mínimo de mortalidade foi de $29 \pm 1,5 \%$ obtido nas temperaturas de incubação. As $T L_{50}$ inferiores foram 15,01 e $16,72^{\circ} \mathrm{C}$ e as $T L_{50}$ superiores foram 29,25 e $27,83^{\circ} \mathrm{C}$ para as larvas incubadas a 21 e $26^{\circ} \mathrm{C}$, respectivamente. Portanto, aparentemente, não há diferença com relação à tolerância a variações de temperatura nas larvas incubadas nas duas temperaturas.

Palavras-chave: Rhamdia quelen, larva, temperatura letal, incubação, jundiá.

Temperature is an important ecological factor because it directly affects fish survival. Although thermal limits have been established for several teleost species (TSUCHIDA, 1995), little information is available for tropical and subtropical species. The silver catfish, Rhamdia quelen, a freshwater fish, is a native species from Southern Brazil that may have potential in fish culture. The objective of the present study was to determine the lower and upper lethal temperatures for $\boldsymbol{R}$. quelen larvae.

Larvae were obtained from two induced spawning during October 1997 and January 1998 at the fish culture sector of the Federal University of Santa Maria. Females and males of $\boldsymbol{R}$. quelen were injected with $5 \mathrm{mg} / \mathrm{kg}$ pituitary extract, and pairs were then placed in a Hungarian-model hatchery

\footnotetext{
${ }^{1}$ This article is part of the master dissertation of A.R. Chippari-Gomes, presented to the graduate course in Animal Husbandry - Universidade Federal de Santa Maria (UFSM).

${ }^{2}$ Biologist, Master in Animal Husbandry.

${ }^{3}$ Oceanologist, Doctor. Adjunct professor, Departamento de Fisiologia, UFSM, 97105-900. Santa Maria, RS, Brazil. E-mail: bernardo@ccs.ufsm.br. Author for correspondence.
} 
(200L) within a water re-use system. Temperatures were $21^{\circ} \mathrm{C}$ in October and $26^{\circ} \mathrm{C}$ in November. After spawning the fish were removed, the eggs were incubated, and the newly hatched larvae were maintained in these hatcheries until absorption of the yolk sac was complete (size of $5.3 \pm 0.2 \mathrm{~mm}$; mean \pm SEM). Larvae were then transferred to continuously aerated $250 \mathrm{~L}$ tanks using a water re-use system at the same temperature as in the hatchery $\left(21^{\circ} \mathrm{C}\right.$ and $26^{\circ} \mathrm{C}$ ). At this moment larvae were fed daily, with fishmeal (granulometry 200 $\mu \mathrm{m}$ ) containing $41 \%$ crude protein, prepared according to ULIANA (1997).

In order to access the lethal temperatures $\left(\mathrm{LT}_{50}\right)$ groups of 40 larvae (two replicates) were transferred to 2 continuously aerated $56 \mathrm{~L}$ aquaria at the same temperatures $\left(21^{\circ} \mathrm{C}\right.$ or $\left.26^{\circ} \mathrm{C}\right)$. At one aquaria larvae were submitted to lower temperatures, while at the other one larvae were exposed at upper temperatures. A $500 \mathrm{~W}$ heater was used to increase the temperature, and a cooling system was used to reduce it, and thermostats were incorporated to fix temperatures and hold them constant. The water was continuously aerated to avoid temperature stratification. Temperatures were increased $1^{\circ} \mathrm{C}$ every $15 \mathrm{~min}$, or reduced $1{ }^{\circ} \mathrm{C}$ every $20 \mathrm{~min}$ until the first larvae presented loss of movement. These temperatures were then fixed and held for $96 \mathrm{~h}$ (BREWER, 1976), and mortality was determined at $24 \mathrm{~h}$ intervals. Larvae were considered dead when presented loss of movement. After this first test, additional experiments were conducted using the same procedure at upper and lower temperatures than that of the initial test (at $2^{\circ} \mathrm{C}$ intervals), until obtaining the maximal $(100 \%)$ and the minimum mortality of the larvae. The minimum mortality index was that observed at the hatching temperature. Larvae were fed daily, even during the experiments, with fishmeal described above.

Ammonia was determined by the method of BOYD (1981), pH with a DMPH-2 pHmeter (Digimed), and dissolved oxygen with a DM4 oxygen meter (Digimed). These chemical parameters were determined during the permanence of the larvae in the 250L tanks, and at the beginning and the end of the experiments in the 56L aquaria. Minimum dissolved oxygen levels were 5.6 and $6.5 \mathrm{mg} / 1$, maximum non-ionized ammonia levels were 0.019 and 0.070 , and $\mathrm{pH}$ range were $6.90-$ 8.16 and $7.71-8.26$ at 21 and $26^{\circ} \mathrm{C}$, respectively.
These chemical parameters of the water were always at good levels for fish culture, according to data reported by BOYD (1981). Mean $\mathrm{LT}_{50}$ were determined from the results obtained at the end of each experiment (time 96h) using non linear regressions (temperature x mortality) calculated with the Slide Write Plus program (Advanced Graphics Software, Inc., tenth edition, July 1993). $\mathrm{LT}_{50}$ was considered the temperature at which $50 \%$ of the group died.

Larvae of $\boldsymbol{R}$. quelen hatched at 21 and $26^{\circ} \mathrm{C}$ showed $100 \%$ mortality at $12^{\circ} \mathrm{C}$ and $35^{\circ} \mathrm{C}$ within a period of 48 and $24 \mathrm{~h}$, respectively. At $16^{\circ} \mathrm{C}$ mortality was $32.5 \%$ and $65 \%$, and at $31^{\circ} \mathrm{C}$ was $45 \%$ and $75 \%$ after $96 \mathrm{~h}$ in larvae hatched at $21^{\circ} \mathrm{C}$ and $26^{\circ} \mathrm{C}$, respectively. In the present study it was not possible to obtain $100 \%$ survival of the larvae. The minimum mortality obtained at $21^{\circ} \mathrm{C}$ was $30 \%$ and at $26^{\circ} \mathrm{C}$ was $27.5 \%$. High mortality is observed in most fish species throughout the larval stage, which is highly susceptible and requires careful handling procedures. Similar results were obtained with larvae of Engraulis mordax, which showed $27.3 \%$ mortality at an acclimation temperature of $12^{\circ} \mathrm{C}$ and $13.3 \%$ at 16 and $20^{\circ} \mathrm{C}$ (BREWER, 1976).

The lower and upper $\mathrm{LT}_{50}$ for larvae acclimated at $21^{\circ} \mathrm{C}$ were 15.01 and $29.25^{\circ} \mathrm{C}$, respectively, while the lower and upper $\mathrm{LT}_{50}$ for larvae acclimated at $26^{\circ} \mathrm{C}$ were 16.72 and $27.83^{\circ} \mathrm{C}$, respectively (Figure 1). Therefore, apparently the tolerance to temperature change of $\boldsymbol{R}$. quelen larvae hatching at $21^{\circ} \mathrm{C}$ was similar to that of larvae hatching at $26^{\circ} \mathrm{C}$. Additional studies with more replicates must be done to solve this doubt.

The mean water temperature in Southern Brazil is $15^{\circ} \mathrm{C}$ in winter and $28^{\circ} \mathrm{C}$ in summer (DMAE, 1993), limiting the number of tropical fish species that can be used in fish culture systems. Previous experiments have demonstrated that $\boldsymbol{R}$. quelen fingerlings are well adapted to low water temperatures (CHIPPARI-GOMES et al., 1999). The recommended hatching range temperature for this species is 16 to $26^{\circ} \mathrm{C}$ (RADÜNZ-NETO, 1981). Some farmers and research centers in South Brazil employ heater systems to maintain $\boldsymbol{R}$. quelen larvae in tanks with water at temperatures near the upper limit of the range described above $\left(24-26^{\circ} \mathrm{C}\right)$. However, the present results show that it is not necessary to acclimate $\boldsymbol{R}$. quelen larvae at these temperatures, since mortality at both incubation 


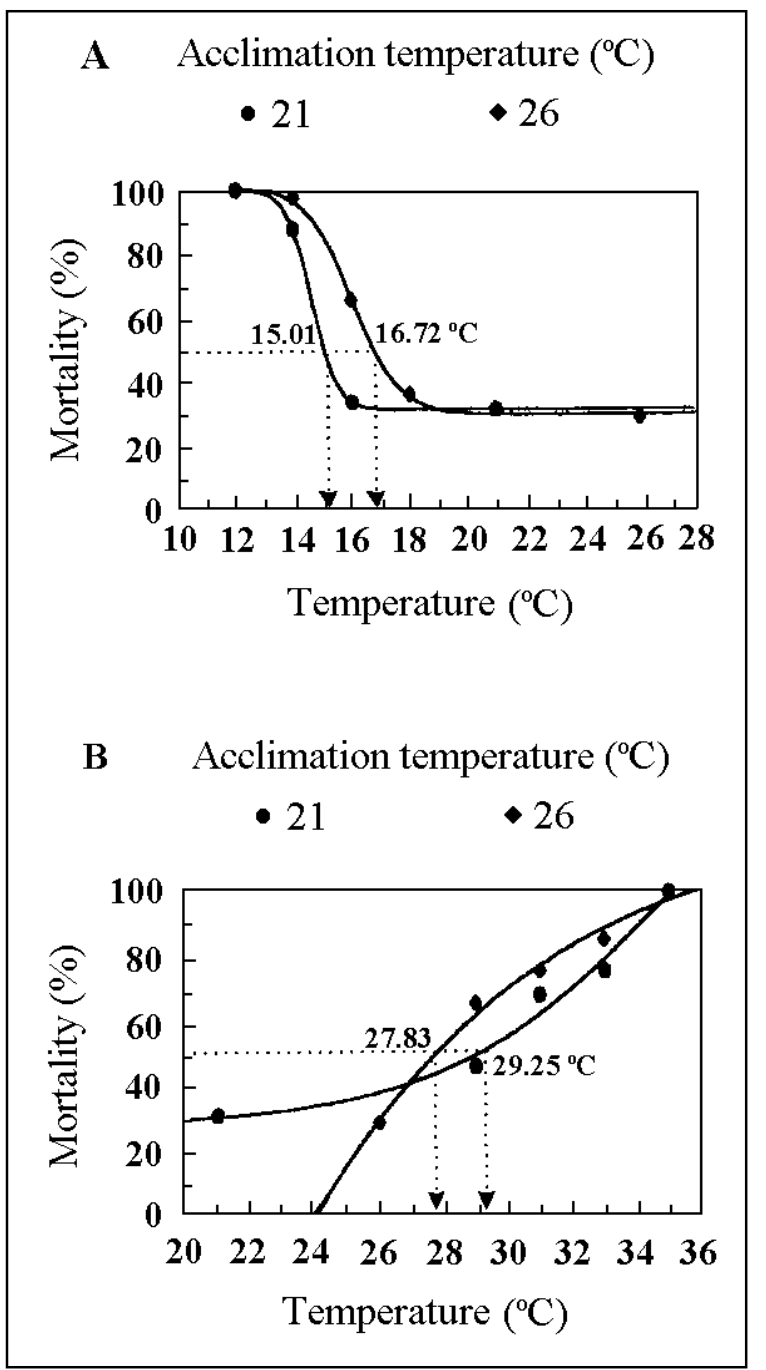

Figure 1 - Lower (A) and upper (B) lethal temperatures $\left(\mathrm{LT}_{50}\right)$ for R. quelen larvae hatched at 21 and $26^{\circ} \mathrm{C}$. The $\mathrm{LT}_{50}$ was accessed from the results of mortality obtained at the end of each experiment (96h). temperatures $\left(21\right.$ and $\left.26^{\circ} \mathrm{C}\right)$ was similar $(27.5$ and $30 \%$, respectively).

\section{ACKNOWLEDGMENTS}

The authors wish to thank CAPES by financial support and to the fish culture sector of the Federal University of Santa Maria for the R. quelen larvae.

\section{REFERENCES}

BOYD, C.E. Water quality management for pond fish culture. New York : Elsevier, 1981. 317 p.

BREWER, G.D. Thermal tolerance and resistance of the northern anchovy, Engraulis mordax. Fishery Bulletin, v.74, n.2, p.433-445, 1976.

CHIPPARI-GOMES, A.R., GOMES, L.C., BALDISSEROTTO, B. Lethal temperatures for silver catfish, Rhamdia quelen, fingerlings. Journal of Applied Aquaculture, v.9, n.4, p.1121, 1999.

DMAE. Estudo da águas represadas na Lomba do Sabão. Revista de Saneamento Ambiental, n.0, p.8-12, 1993.

RADÜNZ NETO, J. Desenvolvimento de técnicas de reprodução e manejo de larvas e alevinos de jundiá (Rhamdia quelen). Santa Maria, RS, 1981. 77p. Dissertação (Mestrado em Zootecnia) - Curso de Pós-graduação em Zootecnia, Universidade Federal de Santa Maria, 1981.

TSUCHIDA, S. The relationship between upper temperature tolerance and final preferendum of Japanese marine fish. Journal of Thermal Biology v.20, p.35-41, 1995.

ULIANA, O. Influência de diferentes fontes e níveis de lipídios sobre a criação de larvas de jundiá (Rhamdia quelen), Pisces, Pimelodidae. Santa Maria, RS, 1997. 66p. Dissertação (Mestrado em Zootecnia) - Curso de Pós-graduação em Zootecnia, Universidade Federal de Santa Maria, 1997.

Ciência Rural, v. 30, n. 6, 2000. 